Abstracta Iranica

Revue bibliographique pour le domaine irano-aryen

Volume 32-33 | 2013

Comptes rendus des publications de 2009-2010

\title{
Rika Gyselen. Primary sources and historiography on the Sasanian Empire
}

\section{Barbara Kaim}

\section{OpenEdition}

1 Journals

Édition électronique

URL : http://journals.openedition.org/abstractairanica/40503

DOI : 10.4000/abstractairanica.40503

ISSN : 1961-960X

\section{Éditeur :}

CNRS (UMR 7528 Mondes iraniens et indiens), Éditions de l'IFRI

\section{Édition imprimée}

Date de publication : 1 décembre 2013

ISSN : 0240-8910

\section{Référence électronique}

Barbara Kaim, «Rika Gyselen. Primary sources and historiography on the Sasanian Empire », Abstracta Iranica [En ligne], Volume 32-33 | 2013, document 161, mis en ligne le 01 juillet 2016, consulté le 26 septembre 2020. URL : http://journals.openedition.org/abstractairanica/40503 ; DOI : https://doi.org/ 10.4000/abstractairanica.40503

Ce document a été généré automatiquement le 26 septembre 2020.

Tous droits réservés 


\title{
Rika Gyselen. Primary sources and historiography on the Sasanian Empire
}

\author{
Barbara Kaim
}

\section{RÉFÉRENCE}

Rika Gyselen. «Primary sources and historiography on the Sasanian Empire ». Studia Iranica, 38/2, 2009, p. 163-190.

Démontrant les lacunes dans la publication de P. Pourshariati, Decline and Fall of the Sasanian Empire, The Sasanian-Parthian Confederacy and the Arab Conquest of Iran (2008), l'A. souligne l'importance des sources primaires.

\section{AUTEURS}

\section{BARBARA KAIM}

Université de Varsovie 